\title{
11 Development as depth: towards a theology of integral human development
}

\author{
Clemens Sedmak
}

In the first book of Samuel, we find the colorful description of a thoughtprovoking scene: the young shepherd, David, is willing to fight Goliath; King Saul gives David his armor and helmet, but David "tried in vain to walk, for he was not used to them" (1 Sam. 17:38-39a). David is too small for the armor, probably the most precious and heaviest of the time.

The image is quite powerful if we translate it into the present situation: we have built huge armors of technological possibilities and agency, but have not grown to match it; we are like moral and spiritual dwarfs in the armor of giants. We still study Aristotle's Nicomachean Ethics. His contributions to science have lost much of their relevance and plausibility, while we have not made enough progress on the grounds of morality to render his moral observations obsolete. There is a disconnect between technological and moral progress, between economic and spiritual growth. In light of the challenges we face with the practices of mining, we have to ask ourselves some deep moral questions. We cannot do without the fruits of mining in our present lives, but we might have to rethink some of the parameters guiding the industry. This concerns especially decisionmaking processes and the interaction between mining activities and local contexts. Technological progress may help, but it is not the main issue. To quote a line from Holden and Montevecchio's chapter for this book: "the idea of removing less from the earth and, instead, getting more out of what has already been extracted or else changing consumption patterns altogether are never considered." These challenges touch upon moral and spiritual questions-and the deliberation of ends. We have, as Pope Francis's $(2015, \$ 105)$ encyclical Laudato $S i$ ' states, "not been trained to use power well." "We have too many means and only a few substantial ends” (\$203).

A theology of integral human development (IHD) is committed to bridging this gap between means and ends, between external progress and inner growth; it is committed to integrating our technological possibilities into our moral and spiritual identity. This article will develop a theology of IHD with a special emphasis on the mining industry. 


\section{Integral human development}

A simple understanding of IHD is a short formula: the development of the whole person and the development of each person. This deceptively simple characterization dates back to 1967, when Paul VI, in Populorum Progressio, wrote about "authentic human development." Development "cannot be restricted to economic growth alone. To be authentic, it must be well rounded; it must foster the development of each person and of the whole person" $(\mathbb{1} 14)$. This concept can be translated into two imperatives: Do not leave anyone behind! Make sure that each dimension of the person counts!

These two imperatives of IHD correspond to the notion of the common good and the notion of human dignity. The common good refers to the flourishing of a community as a community on the basis of the flourishing of each of its members. It is an aspirational concept that can never be fully met. But it expresses the challenge like a thorn in the flesh of social reality: to leave no one behind. Seen in this light, the common good is distinguished from a utilitarian approach that seeks the greatest good of the greatest number. The common good comes with special attention to the most disadvantaged members of a community and sometimes follows the dynamics of the parable of the lost sheep: to "leave the ninety-nine on the mountains and go in search of the one that went astray" (Mt. 18:12). A commitment to IHD implies a commitment to special consideration for the least privileged and least powerful members of a community; in the case of the mining industry, these may be the local population. Especially in a situation of "big business," the reminder that each person's dignity counts may be called for.

The central notion of IHD is human dignity; it refers to an understanding of a dignified life, a life that corresponds to the dignity of the human person. This idea reflects a particular anthropology. It comes with an image of the human person as a multi-layered being that cannot be reduced to a "one-dimensional" existence, just as Herbert Marcuse (2002 [1964]) had described a one-sided and reductionist approach to development. The human person cannot live without bread, but does not live by bread alone. There is an important aspect of "being beyond having" that requires dignity-sensitive development to be humancentered. Human-centered development, in the words of Denis Goulet (1995, 6-7), refers to a primacy of being over having: "Societies are more human, or more developed, not when men and women 'have more' but when they are enabled to 'be more.' The main criterion of development is not increased production or material wellbeing but qualitative human enrichment."

Even though we cannot make unrealistic claims, we can ask the mining industry for a systematic "moral cost" analysis of their economic activities. We can ask for the identification of entry points for moral burdens. 
An exercise of mapping the crucial moral challenges is a necessary step in building a morally sensitive, more humane economy. This concern has been at the basis of an understanding of development as integral.

The idea that IHD is the development of each person and the whole person was inspired by Joseph Lebret, a French Dominican and economist, who worked with sea fisheries in France. There, he observed the negative effects of certain economic developments on local workers, notably exploitation by a foreign industry (Bosi 2012, 253). Lebret coined the term "human economy," i.e., an economy that would be "favourable to human development," to "a fully human life," as he wrote in his 1954 essay "Économie et Humanisme" (quoted in Keleher 2019, 29). A "fully human life" is more than a provision of basic goods but is rooted in a sense of compassion. Compassion is "an existential fellowship with every man [person] who strives to unite the world under a common destiny and to collectively create the structures that the realization of this aspiration calls for. To love is to identify oneself with one's neighbour, with all men [persons], and to create with them the conditions for their self-fulfilment" (Cosmao 1970, 68).

This lofty language can be translated into corporate social responsibility of mining corporations and their sincere engagement with local communities. Raymond Offenheiser's chapter has pointed to some encouraging developments with regard to indigenous rights or the establishment of consent-oriented processes. There have been clearly intentional efforts to pursue a more inclusive approach that takes non-material aspects such as rights into consideration. The idea of a human-centered development committed to an idea of a full human life and the principles of the common good and human dignity can also be translated into an approach in development ethics (see Keleher 2017; 2019). IHD ethics is an important contribution to a way of thinking about development that takes the dignity and the social nature of the human person seriously. The task we face is not ethics but theology. What is specific about a "theology of IHD"?

\section{A theological perspective}

The following reflections offer a "niche product," a general framework for a theology of IHD that can be applied to mining. Since the normative discourse on mining has been spearheaded by ethics rather than theology, I would like to show how theology can add a distinctive voice. Ultimately, the theological perspective is an appeal to reflecting on the ultimate ends. It will not be enough to offer a moral justification for particular means; the fundamental question about the first and last goals have to be raised. The "selling point" of theology is the finiteness of life and resources. In other words, there are natural limits to what can be extracted and all those involved in the industry will die one day. This is the entry point for theological considerations. 
Some people believe in an afterlife, others do not. This difference seems to be comparable to matters of taste, but the implications reach far deeper. The responses to sensitive questions like beginning and end of life issues, the state of suffering, the meaning of terms like "success," "justice," "happiness," or "flourishing" are profoundly affected by this distinction; so are key aspects of the mining industry such as "profit," "maximization," and "shareholder values." This difference is fundamental for the genuine place of theology in intellectual and academic discourses. This difference decides whether "the world" will have the "first word" and "last word," or whether theological values from "beyond the world" will. Wittgenstein famously stated in his Tractatus Logico-Philosophicus $(1922,6.41)$ that "in the world everything is as it is and happens as it does happen." Similarly, we could say that mining operations happen as they happen, following built-in mechanisms of technologically supported maximization of profit. Normative questions enter from a point of view that does not take the factual as the ultimate norm. Theology specifically asks questions from "outside of the world."

Theology anchors our reflective processes. If we compare our intellectual efforts to a performance on a stage, theology provokes the question of which play we are in. To whom are we talking? From where are we talking? What is the drama in which we are participating? Let us call these three questions the audience question, the position question, and the script question. The audience question: who is listening, who is watching? Candidates for an answer would include contemporaries, future generations, but also ancestors and God. Who will be judging us? The position question: From where are we speaking? Are we speaking from the position of a creature? Are we inhabiting the space of a mortal or an immortal being? The script question: What is the point of the drama we are in? Who has the power to shape the drama, especially the beginning and the end? What is our role on the stage of life?

The project of developing a "theology of IHD" is different from an "ethics of IHD." There is an explicit recognition of audience, position, and script in theology, the recognition of a particular anchoring of our reflection. This anchoring is, of course, always contextual. Theology is not a homogenous country, but many different provinces and regions. There are many "theologies of mining," acknowledging local realities, and local challenges. Conflicts are always entry points for normative considerations, and conflicts always have a particular profile and a local history.

All theologies have this commitment to a specific way of anchoring our thoughts, a commitment to a sphere "beyond the world" that guides and frames our intellectual engagement. This anchoring points to the question of first and last values. If people are tempted to dismiss theology as irrelevant, I would point to three things: (a) the question of first and last values is an essential one that cannot be ignored on an existential level; (b) there is the possibility that the story told by religions and reflected on by theologies 
is true; and (c) the vast majority of people on this planet have some kind of religious affiliation with an either implicit or explicit theology to accompany their religious beliefs and practices. This is very much in line with William James's (1985 [1902]) approach in the Varieties of Religious Experience. What can theology offer to the discourse on IHD?

\section{An integral analysis and the foundational text of Laudato Si'}

Laudato Si' (Francis 2015) is an important and influential document that lays the ground for a theology of IHD. It has been dealt with in this book in the chapter written by Anne Floerke Scheid and Daniel P. Scheid. In their contribution the authors have shown how Laudato Si', with its message on integral ecology, is relevant for an understanding of an ecological just peace applicable to mining. Laudato $S i$ ' has contributed to a deepening of the concept of IHD with an ecological perspective $(\$ 141)$ and with a long-term perspective that explicitly considers future generations $(\$ 159)$.

If we take an integral view to mean a holistic approach that brings separate aspects into a shared whole, we can understand the integral and integrating character of Laudato $\mathrm{Si}^{\prime}$ in many ways. The whole document develops the thesis that everything is connected $(\mathbb{S 1 6}, 42,70,92,117,138$, 240). As a consequence, the world's problems cannot be analyzed or explained in isolation $(\$ 61$; cf. $\$ 110,131)$. This integral view comes with the obligation to think in terms of interdependence, "one world with a common plan" (\$164). The integral view, we could say, is an expression of and leads to an ethics of thinking. Let me offer a reference point for a more integral approach.

An integral analysis of the mining industry would take a closer look at the dynamics of "extracting." Extracting is an action that removes something from something else. As Tobias Winright observed in his chapter, it also has the semantic nuance of "force" (if not "violence"): "X extracted information from Y." Here, "extracting" is close to "pulling out forcibly." Etymologically speaking, "extracting" is based on "ex" ("out," "out of") and "trahere" ("draw"). This gives us a first sketch of the key concepts at stake: (a) Extracting is an action (and not an event) that follows agentcausality and intentionality; (b) extracting requires "force;" (c) extracting changes a situation by creating a new ontological state: B is separated from $\mathrm{A}$, changing the state of $\mathrm{A}$ as well as the state of B. A basic analysis of "extract," then, could look like this:

$\mathrm{X}$ extracts $\mathrm{B}$ from $\mathrm{A}$ in $\mathrm{C}$ through $\mathrm{M}$ because of $\mathrm{R}$.

$\mathrm{X}$ is the agent (the subject), B is the extracted material, $\mathrm{A}$ is the source of the extracted material, $\mathrm{C}$ is the context of the operation, $\mathrm{M}$ is the mode of extraction (method, means), $\mathrm{R}$ is the reason or set of reasons ("why"). 
The different elements of this analysis are interconnected. If we apply this simple analysis to mining we might see that the agent is normally a combination of persons and institutions/organizations, that candidates for "B" have multiplied over the years, that the context is recognized to be ecologically and ethically problematic, that the mode has become more and more refined and technologically complicated, and that $\mathrm{R}$ cannot be separated from categories like "profit" or "demand and lifestyle," what Douglass Cassel refers to in his chapter as end uses. This would then immediately bring us into the realm of ethical considerations with issues like: division of moral labor between individuals and institutions; questions of responsibility, sustainability, and accountability; analysis of stake holders with their power structures; or moral deliberations of lifestyle and virtues like temperance and justice. This perspective is an integral part of the analysis, not an optional addition.

This analysis would also allow for an analysis of conflicts if we expand it:

$\mathrm{X}$ extracts $\mathrm{B}$ from $\mathrm{A}$ in $\mathrm{C}$ through $\mathrm{M}$ because of $\mathrm{R}$, affecting $\mathrm{Y}$.

Y would be stakeholders in the process; we can invite an explicit consideration of violated interests through this version:

$\mathrm{X}$ extracts $\mathrm{B}$ from $\mathrm{A}$ in $\mathrm{C}$ through $\mathrm{M}$ because of $\mathrm{R}$, against the interests of $\mathrm{Y}$.

We can also make the potential for conflicts explicit in this version:

$\mathrm{X}$ extracts $\mathrm{B}$ from $\mathrm{A}$ in $\mathrm{C}$ through $\mathrm{M}$ because of $\mathrm{R}$, thereby causing damage to $\mathrm{Y}$.

In this form, the analysis would ask for an explicit reflection on those whose lives, interests, properties, or communities have been damaged by mining. This is not an unrealistic appeal to end mining, but a plea for the proper consideration of the full and integral reality of the act. A commitment to IHD would specifically ask to consider in "Y" the most disadvantaged and least privileged stakeholders.

A theological perspective would add specific connections to this analysis, especially in the justifiability of the mode "M," reflection on the reasons "R," and "weighing" of the stakeholders " $Y$ " in the spirit of a "preferential option for the poor." Particular modes "M" of extraction can be severely problematic in and of themselves, such as the use of cyanide to leach gold from ore. The reasons " $\mathrm{R}$ " can be economic (generation of profit, state revenue) as well as existential (preservation and expansion of capabilities and a form of life). In any case, the question "who benefits" has to be considered a key aspect in this kind of analysis. That is why the explicit and differentiated consideration of stakeholders "Y" will be indispensable. 
Stakeholders of the Essakane mine in Burkina Faso, to name a prominent example, are local communities, regional and national governments, global investors, other mining sites, and global consumers, among others. An integral analysis of the connections between different aspects and different players in the mining industry will lead to contextual ethical reasoning that takes into account the local contexts and dynamics.

\section{Strengthening the theological voice}

A theological analysis can add important aspects to an integral analysis of mining. I want to mention three specific connections that can be distilled from Laudato Si'. First is the connection between the inner world and the outer world: "The emptier a person's heart is, the more he or she needs things to buy, own and consume" (Francis 2015, $\$ 204$ ). This is made even more explicit in a quotation from Pope Benedict (quoted in Francis 2015, \$217): "The external deserts in the world are growing, because the internal deserts have become so vast." Second is the connection between the ecological and the social: "The human environment and the natural environment deteriorate together" $(\$ 48)$, so the cry of the earth and the cry of

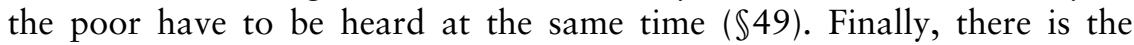
connection between knowledge and pain: we must cultivate a "wound of knowledge," daring "to turn what is happening to the world into our own personal suffering” ( $\$ 19)$.

Laudato $S i$, addresses a number of obstacles to IHD, specifically the phenomenon of "rapidification" $(\$ 18)$, the "technocratic paradigm" $(\$ 109)$, "excessive anthropocentrism" (\$116; cf. $\$ 122)$, "rampant individualism" $(\$ 162)$, the idea of "maximizing profits" $(\$ 109,195)$, and the attitude of "self-interested pragmatism" (\$215). These reference points provide candidates for further questions for our analysis of the dynamics of "extracting."

Most of these aspects seem to be ethical and not theological in nature. A statement characterizing authentic development could be understood in this way: "Authentic development includes efforts to bring about an integral improvement in the quality of human life" $(\$ 147)$. Categories like "improvement" and "quality of life" seem ethical in nature, and there are undeniably building blocks of an ethics of IHD in the encyclical. But a close reading clearly shows that IHD is a theological and not an ethical concept. We find the strong statement: "A spirituality which forgets God as all-powerful and Creator is not acceptable” $(\mathbb{\$} 75)$. This could be related to the warning that the absence of a sense of mystery is destructive: "When nature is viewed solely as a source of profit and gain, this has serious consequences for society" $(\$ 82)$. The reference to "mystery" is not simply a reference to a category; it is a reference to a spirituality, to an attitude towards life as a whole.

We could read the encyclical as an invitation to a two-fold transformation: (a) the ecological crisis cannot be approached with the means of 


\section{Clemens Sedmak}

technological progress; and (b) technological challenges must be transformed into moral concerns. But we cannot stop there. The encyclical invites a further step: moral concerns are translated into spiritual questions (cf. \$202). In consistently offering religious language and religious categories, Laudato $S i$ ' prepares the ground for a particular anchoring of our ecological challenges, for a particular way of framing the stage of the ecological drama.

Dietrich Bonhoeffer pursued a project of translating religious terms into non-religious language in the 1930s and 1940s. The encyclical seems to do the opposite. We see the project of translating non-religious terms in religious language: "nature" becomes "creation" $(\mathbb{S 7 6})$, "land" becomes "a gift from God" $(\$ 146)$, "animals" become "creatures reflecting something of God" (\$221), human life becomes a journey "towards the sabbath of eternity" ( $\$ 243)$. This religious hermeneutics of the world is part of a sacramental view where "there is a mystical meaning to be found in a leaf, in a mountain trail, in a dewdrop, in a poor person's face" $(\$ 233)$. The roots of the environmental crisis are recognized as "ethical and spiritual” $(\$ 9)$. The theological perspective of Laudato $S i$ ' is made explicit in the engagement with Patriarch Bartholomew's language of "sin" as it mentions human-made changes to the climate by contaminating the earth's waters, its land, its air, its life $(\$ 8)$. The patriarch is also quoted with a characterization of the world "as a sacrament of communion" $(\$ 9)$, thus inviting a sacramental view of the universe that connects the visible with the invisible, that sees the world as an expression of divine will and love, as "a magnificent book in which God speaks to us" (\$12; cf. $\$ 85)$.

A theological perspective accepts the commitment to not leaving the first word and the last word to this world. In fact, the encyclical points out, creation is harmed, according to an address by Pope Benedict XVI, "when we ourselves have the final world" (Francis 2015, \$6). And here, one of the fundamental theological statements comes in: "We are not God” (\$67).

What is the connection, we could ask, between this theological depth of Laudato Si, mining, and peacebuilding? The answer would be a matter of the level of responses. Conflicts point to deeper issues than a clash of material interests; there are issues like identity, tradition, and honor involved. Conflict resolution cannot be reduced to a technique, but has to be built on trust and reconciliation. The response to the environmental crisis is an ecological conversion, a particular asceticism (\$9). A faith perspective can provide motivation to care for nature and the most vulnerable persons $(\$ 64)$, motivations "which make it possible for us to live in harmony, to make sacrifices and to treat others well" $(\$ 200)$. The category of "sacrifice" refers to a fundamental re-ordering of priorities. These are the deep questions that theology can evoke. 


\section{Development as depth}

The theological (rather than ethical) nature of Laudato Si' leads to an understanding of development that cannot be grasped in key terms of moral philosophy like "freedom" or "fairness." These terms are important, but a theological reading of the world and of the relationships within the world touches a dimension that allows and asks for categories such as "mystery," "gift," "meaning," and "service."

Ultimately, the encyclical presents us with a vision of "development as depth." Development, as presented in Laudato Si', is not primarily about progress and living standards; it is not even about maximizing freedoms and quality of life. In one particular passage, Pope Francis introduces the term "depth in life" $(\$ 113)$, which criticizes the superficiality created by the accumulation of constant novelties. This thought presents an alternative to a certain understanding of progress. In fact, the encyclical calls for a change of direction. IHD requires deep change $(\$ 60)$. This change can be linked to a particular understanding of moral and personal growth (\$127), growth anchored in deep commitments that may even motivate sacrifices. This is a vision of IHD that is explicit about the cost of "integrating," of accepting vulnerable beings, "however troublesome or inconvenient" $(\$ 120)$.

Here, we move in an area that transcends the language of "quality of life." Let me illustrate the difference between "quality of life" and "depth of life" with an example. Walter Jens was one of the most prominent public intellectuals in Germany. Around 2003, when he was eighty years old, he was diagnosed with dementia. His wife, Inge, accepted caregiving responsibilities and talked about her experience in both the final chapter of her autobiography and in a moving book (Jens 2009; 2016). Jens's words are imbued with melancholy about the loss of a conversation partner, of a "Thou," of the person she loved for decades. Clearly, the quality of life of Inge Jens diminished significantly during those years. But she could not not live with her husband, care for him, look after him. This is an expression of a deep commitment that could better be captured by the term, "depth of life."

"Depth of life" points to the identity issues at stake in most conflicts. When rural or indigenous communities face losses from a mining project that is supposedly good for economic development, they may officially gain access to higher "living standards," but they lose identity-conferring aspects of their lives. Andrés McKinley discusses in his chapter how the anti-mining movement, of which the Church in El Salvador was a major leader, used the slogan "Yes to Life, No to Mining." This "Yes to Life" is spoken on a level that is deeper than the material dimension of human existence. It can be framed in spiritual terms. Coming back to conflict resolution we can see that McKinley's emphasis on the commitment of the movement to nonviolent action and legislative transformation is based on a spirituality of 
encountering people and of encountering problems, a spirituality based in a sense of "what really matters" in a local context. Respecting notions of what really matters locally is an indispensable aspect of any peacebuilding effort. Peacebuilding intends to lead to "peace of mind," a spiritual category connected to the idea of what makes life deep and rooted.

Peacebuilding cannot ignore the deep roots of people and communities. Simone Weil, the French philosopher with a deep sense of the spiritual, was asked in 1943 by the Free French Resistance to write a text about rebuilding France (and Europe) after the war. She was asked to reflect on peacebuilding and peaceful rebuilding. In response, Weil (1949) chose to consider not so much structures and institutions, but the needs of the soul. The text, posthumously published under the title L'Enracinement (The Need for Roots), talks about the need to address the moral and spiritual malaise of the time, the need to respond to the dissolution of community by recognizing duties towards humanity. This is the level on which to address the roots of conflicts-on the level of existential roots.

Depth of life is the existential situation of a person who deeply cares about someone or something. This robust concern structures life and gives it weight and profoundness. A theology of IHD will also ask for the integration of suffering, woundedness, vulnerability, limits, and loss. There is a sense of immeasurability and non-functionality. The dignity of the human person is not defined by "functioning well" or by "visible achievements." As Laudato Si' expresses, "We forget that the inalienable worth of a human being transcends his or her degree of development" (Francis 2015, $\$ 136$ ). The theological vision of development articulated in Laudato Si' is a vision of the kind of depth that accepts the cross as a motif of human development. This understanding of depth is built on the foundation of commitments that are love-filled and love-shaped relationships. When we read that "social love is the key to authentic development" (\$231), we can see the movement from individual freedoms to social commitments, from personal development to inner growth, from quality of life to depth of life. This is not to say that individual freedoms, personal development, and quality of life are not important. The claim is only that there is a genuine contribution by theology that ethics is not able to offer. Even though there can be an ethical understanding of "social love," the theological meaning cannot be separated from a sense of God's love for creation and God's creatures.

Obviously, this religious sense cannot be presupposed or imposed. But framing mining in terms of "extracting resources from creation" rather than "extracting resources from nature" can provide a helpful perspective for understanding the position of local communities that are, more often than not, rooted in faith traditions. Furthermore, the category "depth of life" is a reminder of a dimension of human existence that cannot be measured, let alone expressed in a language of "risk management," "convenience," or "profit." A theological understanding of development 
is always at the same time external change and internal transformation. What is being extracted in a mining operation is, then, not only material, but also identity resources. This dynamic has to be taken seriously in the attempt to understand the deeper dimensions of conflicts.

\section{An integral theology of mining and peacebuilding}

On May 3, 2019, Pope Francis addressed participants at a meeting on the mining industry. He criticized a particular economic model, "voracious... profit-oriented, shortsighted, and based on the misconception of unlimited economic growth" (n.p.). "Mining for the common good" means mining that it is at the service of the entire human community in the light of the universal destination of goods with a special place of local communities at the table (cf. Francis $2015, \mathbb{\$} 183$ ). Especially vulnerable communities like indigenous communities have to be protected and specifically invited. Mining for the common good also means that it serves the human person with special consideration of human rights. Pope Francis also called attention to a "throwaway culture" and the moral necessity to organize mining operations around a model of a circular economy.

These papal exhortations are framed in theological language, not merely in ethical terms. Francis (2019, n.p.) explicitly refers to a fundamental spiritual attitude: "religious traditions have always presented temperance as a key component of a responsible and ethical lifestyle. Moderation is also vital to save our common home. 'Blessed are the meek, for they shall inherit the earth' (Mt. 5:5)." We leave the context of arguments here and move into the realm of faith narratives which play an important role in the lives of communities. And we reach a context where a spirituality of peacebuilding becomes tangible.

The transformation that Laudato Si' calls for and the theological perspective expressed in the encyclical are relevant for the mining industry. Again, there is legitimate space for ethics, as there are many moral challenges with regard to mining: issues with inequality, environmental damage, health risks (Anaf et al. 2019), conflict, and gender issues. The latter include loss of livelihoods through mining, exploitation of women in artisanal mining, sexual exploitation in mining areas, gender effects of mininginduced community changes, and gendered micropolitics of resistance (Adamson 2017; Jenkins 2015; 2017; Macdonald 2018). There is an undeniable need for an "ethics of mining," given the lack of laws and frameworks. There is a need for a global ethics that recognizes "resource interdependence" and the need to consider "international relations of natural resources" (Siegel 2013, 9). There is also a need for the development of legally binding regulations and a role for legislation in creating structures of accountability.

Raymond Offenheiser, in his chapter for this book, discusses the need for "ethics" in the industry; he also points to the necessity of an inclusive 
dialogue by underlining the need for religious actors to understand the mining industry mindset. This is one side of the matter. The other would be a dialogue that moves beyond ethics and helps agents from the mining industry to understand the concerns and categories of faith-based persons and communities. Understanding the difference between ethics and theology is a first step. Even non-religious persons hold comprehensive ideological commitments and do not stand on neutral ground with regard to the first and last questions asked by theology. The situation we find ourselves in, confronted with the finite nature of our resources, calls for fundamental questions. And this is where I see the place of theology.

Ethics can recommend proper consideration of ecological systems in their sustainability and of communities in their integrity (cf. Carvalho 2017). It can recommend a proper consideration of the human and moral costs of conflicts in mining contexts; it can call for a proper analysis of the losses of vulnerable local communities. Ethics can reflect on the economic macroconditions and the normative implications of a paradigm of economic adjustment. As part of a "geoethics," an ethics of mining can develop the concept of "responsible mining" (Bice 2016), calling for a proper consideration of stakeholders, a dialogue-centered and community-based approach to the development of sites, appropriate efforts towards environmental protection and ecological sustainability with integrated waste management and energy saving systems, and the provision of a safe and healthy work environment with appropriate remuneration. These elements could ensure that any operation of the extractive industries is embedded in an integral approach that respects the dignity of the person.

There is a lot that an IHD ethics approach to mining can do. But there is also space for a theological approach to mining: Laudato Si' mentions mining activities in the context of the pollution of underground water sources (Francis $2015, \mathbb{\$ 2 9}$ ). What would be added to the discourse if the stakeholders of the mining industry were willing to work with categories like "creation," "creature," "sin," and "soul"? Would it make a difference to think about the mining industry in terms of "penultimate life" and the world as having the second and the penultimate word, but not the first and the final? Would it make a difference to turn to the spiritual? Laudato Si' states: "There needs to be a distinctive way of looking at things, a way of thinking, policies, an educational programme, a lifestyle and a spirituality which together generate resistance to the assault of the technocratic paradigm" (\$111). Francis makes an explicit call to "an ecological spirituality" $(\$ 216)$; this spirituality includes tenderness and compassion $(\$ 91)$, an awefilled contemplation of creation $(\$ 125)$, a sense of receptivity and gratuity $(\$ 237)$, and a deep sense of beauty (cf. $\$ 97,112$ ). Would it make a difference to introduce the idea of a "spirituality of mining" into the discourse on the extractive industries?

The most concrete imperative that follows from an integral human theology on mining that is committed to an understanding of respect for 
creation is the rejection of the principle of the maximization of profits (cf. Francis 2015, $\$ 195$ ). The idea of maximization points to a human tendency to strive for more. There is no saturation point. There can always be more goods and more profit. With the absence of a saturation point there are two possibilities: external limits (legal restrictions, depletion of resources) or internal limits (a sense of "enough"). The latter requires an attitude towards life as such and towards the world as a whole-in other words, it requires a spirituality. I would like to suggest that a fundamental implication of a theology of IHD approach to mining is the rejection of the idea of a maximization of profits and the acceptance of self-imposed limits. As the Congregation for the Doctrine of the Faith and the Dicastery for Promoting Integral Human Development $(2018, \$ 10)$ point out, "No profit is in fact legitimate when it falls short of the objective of the integral promotion of the human person, the universal destination of goods, and the preferential option for the poor." It seems plausible to make this a standard for justifying mining profits given the industry's massive impact on the planet. The burden of proof moves to those who make profits. And a legalistic answer ("it is not against the law") will not do given the idea of a universal destination of goods and the interests of future generations. This, again, is a spiritual dimension, as it touches upon a fundamental existential position, a way of "being-in-the-world." It points to an understanding of "depth of life."

Given the state of the planet, we need to embrace new beginnings. We need to grow and we need to get rid of the huge armor that we have built, armor that only distances ourselves from the mystery of creation. This cannot happen on the basis of propositions, be they ethical, be they theological: "A commitment this lofty cannot be sustained by doctrine alone, without a spirituality capable of inspiring us” (Francis 2015, $\$ 216$ ).

\section{References}

Adamson, Rebecca. 2017. "Vulnerability of Women in Extractive Industries." ANTYAJAA: Indian Journal of Women and Social Change 2, no. 1: 24-31. 10. $1177 \% 2 F 2455632717714134$.

Anaf, Julia, Fran Baum, Matthew Fisher, and Leslie London. 2019. "The Health Impacts of Extractive Industry Transnational Corporations: A Study of Rio Tinto in Australia and Southern Africa." Globalization and Health 15, no. 13. 10. 1186/s12992-019-0453-2.

Bice, Sara. 2016. Responsible Mining: Key Principles for Industry Integrity. London: Routledge. 10.4324/9781315765679.

Bosi, Alfredo. 2012. "Economia et humanismo." Estudos Avançados 26, no. 75 : 249-266. 10.1590/S0103-40142012000200017.

Carvalho, Fernando P. 2017. "Mining Industry and Sustainable Development: Time for Change." Food and Energy Security 6, no. 2: 61-77. 10.1002/fes3.109.

Congregation for the Doctrine of the Faith and the Dicastery for Promoting Integral Human Development. 2018. “'Oeconomicae et pecuniariae quaestiones.' 
Considerations for an Ethical Discernment Regarding Some Aspects of the Present Economic-Financial System.” May 17, 2018. https://press.vatican.va/ content/salastampa/en/bollettino/pubblico/2018/05/17/180517a.html.

Cosmao, Vincent. 1970. "Louis-Joseph Lebret, O.P. 1897-1966: From Social Action to the Struggle for Development." New Blackfriars 51, no. 597: 62-68. 10.1111/j.1741-2005.1970.tb02029.x.

Francis. 2015. Laudato Si'. http://www.vatican.va/content/francesco/en/encyclicals/ documents/papa-francesco_20150524_enciclica-laudato-si.html.

Francis. 2019. "Address to Participants at the Meeting Promoted by the Dicastery for Promoting Integral Human Development on the Mining Industry.” May 3, 2019. http://www.vatican.va/content/francesco/en/speeches/2019/may/documents/papafrancesco_20190503_incontro-industria-mineraria.html.

Goulet, Denis. 1995. Development Ethics: A Guide to Theory and Practice. London: Zed.

James, William. 1985. Varieties of Religious Experience. Cambridge, MA: Harvard University Press.

Jenkins, Katy. 2015. “Unearthing Women's Anti-Mining Activism in the Andes: Pachamama and the 'Mad old Women." Antipode 47, no. 2: 442-460. 10.1111/ anti.12126.

Jenkins, Katy. 2017. “Women Anti-Mining Activists' Narratives of Everyday Resistance in the Andes: Staying Put and Carrying on in Peru and Ecuador." Gender, Place and Culture 24, no. 10: 1441-1459. 10.1080/0966369X.2017. 1387102.

Jens, Inge. 2009. Unvollständige Erinnerungen. Reinbek bei Hamburg: Rowohlt.

Jens, Inge. 2016. Langsames Entschwinden. Reinbek bei Hamburg: Rowohlt.

Keleher, Lori. 2017. “Toward an Integral Human Development Ethics.” Veritas 37: 19-34. 10.4067/S0718-92732017000200019.

Keleher, Lori. 2019. "Integral Human Development." In Routledge Handbook of Development Ethics, edited by Jay Drydyk and Lori Keleher, 29-34. 10.4324/ 9781315626796.

Macdonald, Catherine. 2018. "The Role of Gender in the Extractive Industries.” In Extractive Industries: The Management of Resources as a Driver in Sustainable Development, edited by Tony Addison and Alan Roe, 442-459. Oxford: Oxford University Press. 10.1093/oso/9780198817369.003.0021.

Marcuse, Herbert. 2002 [1964]. One-Dimensional Man: Studies in the Ideology of Advanced Industrial Society. New York: Routledge. 10.4324/9780203995211.

Paul VI. 1967. Populorum Progressio. https://www.vatican.va/content/paul-vi/en/ encyclicals/documents/hf_p-vi_enc_26031967_populorum.html.

Siegel, Shefa. 2013. "The Missing Ethics of Mining.” Ethics \& International Affairs 27, no. 1. https://www.ethicsandinternationalaffairs.org/2013/the-missing-ethicsof-mining-full-text/.

Weil, Simone. 1949. L'enracinement. Prélude à une déclaration des devoirs envers l'être humain. Paris: Éditions Gallimard.

Wittgenstein, Ludwig. 1922. Tractatus Logico-Philosophicus. London: Kegan Paul. 